Acta Technologica Agriculturae 3

Nitra, Slovaca Universitas Agriculturae Nitriae, 2014, pp. 66-69

\title{
COMPANY STRATEGY DETERMINATION IN FOOD COMPANY USING SWOT METHOD
}

\author{
Manuela INGALDI*, Katarína LESTYÁNSZKA ŠKŮRKOVÁ \\ ${ }^{1}$ Czestochowa University of Technology, Poland \\ ${ }^{2}$ Slovak University of Technology in Bratislava, Slovak Republic
}

\begin{abstract}
Strategy is a high-level plan to achieve one or more goals under conditions of uncertainty. Strategy becomes necessary when it is known or suspected there are insufficient resources to achieve these goals. To choose a good strategy, it is important to check first the strategic position of a company. The SWOT analysis is a very useful tool to do so. Everyone almost every day buys food to live. For people, it is very important to buy food with good quality at a low price. That is why the authors chose a food company to check its strategic position. In this paper, the strategic position of the chosen food company was specified. This allowed assessing the current situation of the company and to determine the direction of its future activities. The company should use the maxi-maxi strategy.
\end{abstract}

Keywords: SWOT analysis, strategic position, food industry

Every company plans its activities in advance. One type of such plans is a strategic plan. To choose a good strategy, it is important to check first the strategic position of the company. The SWOT analysis is a very useful tool to do so. This analysis answers two questions: under what circumstances the company works and will work in the near future, and what has to do to adapt to these circumstances. With such an analysis, favourable and unfavourable conditions may be indicated, and thus it can be decided which of them the company should use and which to avoid.

In this paper, the strategic position of the chosen company from dairy industry was specified. This allowed determining the direction of future activities of the company. The strengths and weaknesses were identified as well as exterior opportunities and threats. These four groups determined the point in a Cartesian coordinate system showing the strategic position of the company. It was found that the company should use the maxi-maxi strategy.

\section{Company}

The company is one of the leading dairy producers in south-eastern Poland. In 2010, it occupied the sixth place in the list of leading dairy cooperatives. In 2005, it launched a new 'filler' to drink milk and bottled creams and opened a branch of production that allowed expanding the range of half-fat cottage cheese in the popular form of slices. In 2006, the company opened also a smokehouse, which allowed extending the range of cheeses by smoked cheeses. In 2008, the Italian type of cheese was introduced in sales. In subsequent years, the assortment was extended by a completely new type of product - Paradise cottage cheese, and the installation of an automated packaging line for cups in the tray was completed.

Currently, the company buys raw milk from 2,361 suppliers. The annual milk collection in 2012 was approximately 102 million litres. The company offers a wide range of dairy products sold to both domestic and foreign markets. It offers the following products:
- milk and dairy drinks (drinking milk, natural yoghurt, kefir, buttermilk, natural, strawberry-flavoured buttermilk, curdled milk);

- cream: $12 \%, 18 \%, 22 \%$;

- butter;

- curd and cottage cheese;

- Dutch, Swiss-Dutch, Swiss-type cheeses, smoked, sliced cheese;

- fruit-flavoured, vanilla, strawberry, peach, cherry, chocolate cream cheese with a delicate ground.

\section{Material and methods}

The SWOT analysis (alternatively SWOT Matrix) is one of the most popular analytical methods. This method allows identifying strengths, weaknesses, opportunities and threats through analysing the internal and external business environment (Pustějovská et al., 2012). This analysis is a tool to optimize the business management strategy or build a new strategic plan. The main objective of this study is to determine the current position of the test object, its prospects, and with the best strategies (Konstanciak, 2012).

The SWOT analysis can be carried out for a product, place, industry or person. It involves specifying the objective of a business venture or project and identifying the internal and external factors that are favourable and unfavourable to achieve that objective. The method is credited to Albert Humphrey, who led a convention at Stanford Research Institute (now SRI International) in the 1960s and 1970s using data from Fortune 500 companies. The degree to which the internal environment of the company matches with the external environment is expressed by the concept of strategic fit (Prusak et al., 2012).

Setting the objective should be done after the SWOT analysis has been performed. This would allow achievable goals or objectives to be set for the organization (Lestyánszka Škůrková et al., 2011). 
The results of the SWOT analysis contain four groups of statements (Koźmiński et al., 2012):

- strengths: characteristics of the business or project that give it an advantage over others;

- weaknesses: characteristics that place the team at a disadvantage relative to others;

- opportunities: elements that the project could exploit to its advantage;

- threats: elements in the environment that could cause trouble for the business or project.

The SWOT method allows the separation of the four potential strategic situations (Krupski, 2007; Jereb et al., 2013): - SO - maxi-maxi strategy - strategies that use strengths to maximize opportunities. The company needs to distinguish and list the strengths that could aid in the maximization of each one of its listed opportunities. For example, possible strengths that could help the company penetrate a new market could include high-brand recognition, highbrand loyalty, large levels of research and development spending, and superior customer service.

- WO - mini-maxi strategy - strategies that use strengths to minimize threats. To illustrate, consider a company that faces rising labour costs in its home country. Simultaneously, it has identified an attractive opportunity to outsource some of its operations to another country where the cost of labour is far cheaper. This outsourcing prospect reduces the company's threat of rising labour expenses.

- ST - maxi-mini strategy - strategies that use strengths to minimize threats. For instance, a potential threat to a company could be the loss of market share to a new competitor entering the market. One way the company could protect its position involves developing a marketing campaign emphasizing its superior customer service or its competitor's inferior customer service.

-WT - mini-mini strategy - strategies that minimize weaknesses and avoid threats. This section matches the company's threats and weaknesses in order for the company to recognize the potential situations that could harm its operations. Once these possible conditions are realized, the company can conceive of ways to protect its business. For example, the company can enter into a strategic alliance or merge with one of its competitors to protect its operations from a rival company. Moreover, the options to withdraw from a market or suspend operations are always present.

To determine the strategic position of the food company, the internal analysis, in which strengths and weaknesses have been pointed out, and the external analysis, which allowed determining the opportunities and threats in the environment of the company, were done. The steps to assess the strategic position of the company were carried out in stages. The first step was to diagnose strengths and weaknesses and emerging opportunities and threats in the company. The next action was to assign a weight in each group; when added, must score 1 . The next step was to attribute the evaluation of severity in a five-point Parker scale to each factor. The products of weight and evaluation and also weighted averages in each group were calculated (Ingaldi, 2013; Dziuba et al., 2011).

\section{Results and discussion}

Tables 1-4 present the classification of each group of factors having an influence on the strategic position of the food company.

The SWOT analysis allows determining the strategic position of the company. The strategy that should be taken by this company is shown as the point in the coordinate system (Figure 1). To determine the coordinates of the point, the following calculation was made:

$$
\begin{gathered}
X=\mid \text { strengths }|-| \text { weaknesses } \mid=4.24-3.60= \\
=0.64 \text { (for strengths) } \\
\begin{array}{c}
Y=\mid \text { opportunities }|-| \text { threats } \mid=4.55-2.65= \\
=1.9 \text { (for opportunities) }
\end{array}
\end{gathered}
$$

Quantitatively analyzing the different parts of the

\begin{tabular}{|c|c|c|c|}
\hline Element & Weight & Evaluation & Product \\
\hline High-class production machines & 0.1 & 3 & 0.3 \\
\hline Using the latest technologies & 0.1 & 4 & 0.4 \\
\hline Good organization of milk collection & 0.05 & 4 & 0.20 \\
\hline High quality of products & 0.07 & 4 & 0.28 \\
\hline Excellent knowledge of industry & 0.05 & 2 & 0.1 \\
\hline Qualified staff & 0.04 & 4 & 0.16 \\
\hline Experienced management team & 0.04 & 4 & 0.16 \\
\hline Good means of transport: car refrigerator & 0.02 & 1 & 0.02 \\
\hline Wide range of products & 0.03 & 4 & 0.12 \\
\hline HACCP certificate & 0.2 & 5 & 1.00 \\
\hline Implemented ISO 9001:2008 system & 0.3 & 5 & 1.50 \\
\hline Weighted average & & & 4.24 \\
\hline
\end{tabular}
SWOT method, it can be seen that there were reported more strengths of the company and threats from the

Table 1 Classification of strengths of the company 
Table 2 Classification of weaknesses of the company

\begin{tabular}{|l||c|c|c|}
\hline Element & Weight & Evaluation & Product \\
\hline \hline Small scale of production & 0.20 & 4 & 0.80 \\
\hline High energy costs & 0.10 & 2 & 0.20 \\
\hline No intensive advertising campaign & 0.40 & 3 & 1.20 \\
\hline High labour costs & 0.10 & 4 & 0.40 \\
\hline Low share of exports in sales & 0.20 & 5 & 1.00 \\
\hline Weighted average & & & 3.60 \\
\hline
\end{tabular}

Table 3 Classification of opportunities of the company

\begin{tabular}{|l||c|c|c|}
\hline Element & Weight & Evaluation & Product \\
\hline \hline Development of dairy industry & 0.4 & 5 & 2.00 \\
\hline Development of technology & 0.15 & 5 & 0.75 \\
\hline Advent of new customers & 0.2 & 4 & 0.8 \\
\hline Possibility of extending the range of products & 0.25 & 4 & 1.00 \\
\hline Weighted average & & & 4.55 \\
\hline
\end{tabular}

Table 4 Classification of strengths of the company

\begin{tabular}{|c|c|c|c|}
\hline Element & Weight & Evaluation & Product \\
\hline Competitive prices of similar products & 0.15 & 4 & 0.60 \\
\hline Cattle diseases & 0.10 & 4 & 0.40 \\
\hline High cost of modernization of farms & 0.20 & 2 & 0.40 \\
\hline High cost of valuable compound feed for cattle & 0.15 & 1 & 0.15 \\
\hline Retraining of holdings in other than milk production & 0.30 & 3 & 0.90 \\
\hline High EU sanitary requirements & 0.10 & 2 & 0.20 \\
\hline Weighted average & & & 2.65 \\
\hline
\end{tabular}

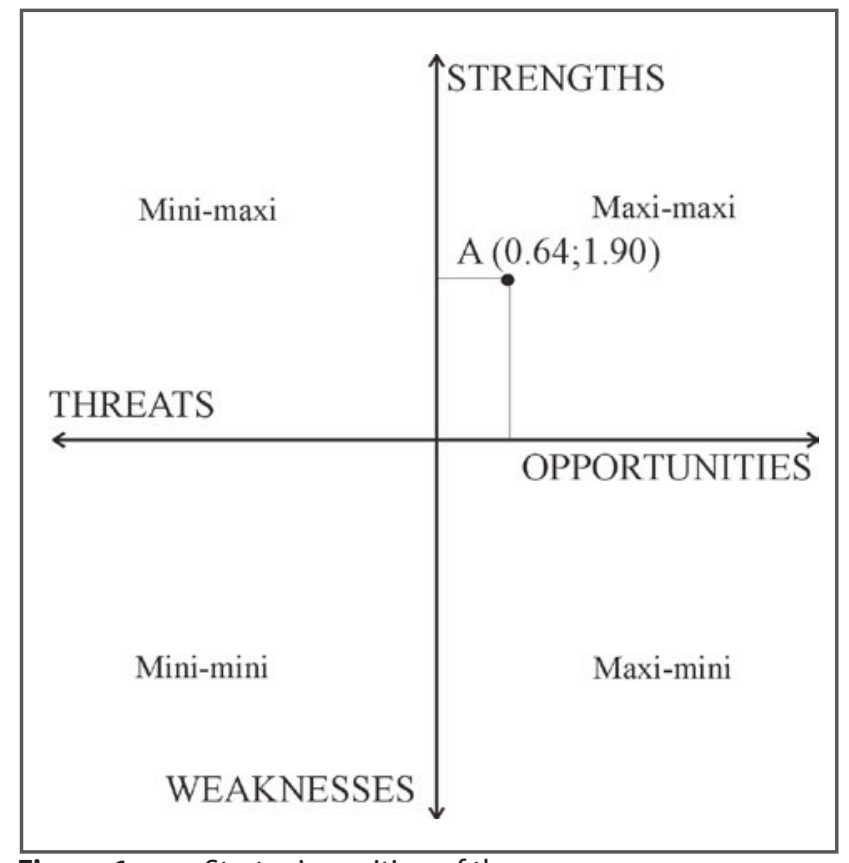

Figure 1 Strategic position of the company environment. The major strengths of the company include the HACCP certificate and implemented ISO 9001:2008 system. This means the products are of high quality, with no food contamination. However, the greatest threats include competitive prices of similar products, that is fierce competition in the market and cattle diseases.

In case of weaknesses, the low share of exports in sales deserves special attention, which implies the need to acquire foreign markets and expand business. However, in case of opportunities, the development of dairy industry and the development of technology are the most important. This gives the company great opportunities to develop.

The valuable analysis of different parts of the SWOT method allowed determining the accurate strategic position of the company. This strategy has been identified as the point A in Figure 1. This is the maxi-maxi strategy, it means aggressive strategies. The company should seek to maximize synergies occurring between opportunities in the environment and strengths of the company. It is a strong development expansion strategy of entering into new markets, investing and continuing to building competitive advantage.

\section{Conclusion}

The SWOT analysis in the chosen food company was conducted. This analysis aimed to determine the strategic 
position of the company and determine the directions of its future activities. The strengths of the company, its opportunities, but also weaknesses and threats were identified. The results will be used by managers of the company.

Figure 1 and the determined point A indicate that the company was included in the maxi-maxi strategy sector, it means aggressive strategies. In this company, strengths predominate over weaknesses and opportunities over threats. The strategy of the company should aim to maintain this position and to make market expansion.

By determining the strategic position, it was possible to identify directions of future activities of the company. The analysis of various groups of factors relating to the company's strategic position allowed for their determination.

The basic strengths of the company are using the latest technologies, high-class production machines and high quality of products. A good organization of milk collection and excellent knowledge of the industry in which the company operates is also very important, especially for prospering of the company. The implemented ISO 9001:2008 system and HACCP certificate (even if obligatory) proves that the company takes care of the quality of its products.

The continuous development of the dairy industry and technologies are considered opportunities for the company. These key elements can become a catalyst to further improve both the company and its market position. The company should invest in its development in order to gain new customers and new markets (expansion). It should be a good idea to watch carefully competitive companies and foreign markets in order to introduce new products. Poland has a great opportunity to conquest the eastern market, especially Ukrainian, because Polish products are known there as being very good if it comes to quality and as quite cheap in comparison to western countries' products. There are also many Polish people in Ukraine who choose products from their original country.

Despite of the good strategic position, the company should closely observe the environment. The major problem faced by other dairies is the reduction of the amount of milk on the market. This risk is partly due to the economic situation in the country and high EU requirements regarding sanitary conditions in farms. Many existing agricultural producers specialized in the production of milk decide to reclassify their holdings to another production - more profitable. Serious problems are also connected with cow disease and the high cost of valuable compound feed, which also results in a reduction in the amount of milk.

Also this company has its weaknesses. However, they can become its strengths after restructuring of marketing activities - mainly promotions and activities related to expansion of the export market. No intensive advertising campaign is the most important weakness of this company. By increasing expenditure on advertising, participation in various campaigns to promote healthy lifestyles, shares in charity or sponsoring for example a regional dairy brand football team, the company can become more well-known and popular, which will result in higher sales in the future.
It should be pointed out that the point in the Cartesian coordinate system is in a position suggesting that the positive factors only slightly are greater than the negative factors. The company's situation is actually very difficult to define. The point located near the centre of the Cartesian coordinate system may be displaced in fact in a short time under the influence of changes in the number of factors involved, and at the same time, the strategic situation of the company can also change. Therefore, this analysis will be repeated in the near future (in one or two years) to see whether directions of actions in the company were welldefined and the strategic position of the company changed in some way.

\section{References}

DZIUBA, S.T. - SZOŁTYSEK, K. - KOZYRA, C. 2011. Application of FAM (fail assessment method) to optimization of unit costs of producing flours for special purposes. Chapter 3. In BORKOWSKI, S. - KRYNKE, M. Improvement of production process (monograph). Trnava : Publisher Tripsoft, 2011, pp. 28-39. ISBN 978-80-89291-46-5.

INGALDI, M. 2013. Problemy zarządzania produkcją W przedsiębiorstwie branży spożywczej. In SEROKA-STOLKA, O. Współczesne problemy zarządzania małym i średnim przedsiębiorstwem (monografia). Czestochowa : Sekcja Wydaw. WZ PCzest, 2013, pp. 198-210. ISBN 978-83-63500-39-9.

JEREB, B. - IVANUŠA, T. - ROSI, B. 2013. Systemic thinking and requisite holism in mastering logistics risks: the model for identifying risks in organizations and supply chain. In Amfiteatru Economic, 2013, vol. 15, no. 33, pp. 56-73.

KONSTANCIAK, M. 2012. Analysis of technological strategies on the example of production of tramway wheels. In Archives of Materials Science and Engineering, vol. 57, 2012, no. 2, pp. 69-74.

KOŹMIŃSKI, A.K. - PIOTROWSKI, W. 2012. Zarządzanie. Teoria i praktyka. Warszawa: Pub. Wydawnictwo Naukowe PWN, 2012. ISBN 978-83-01-16441-6.

KRUPSKI, R. 2007. Zarządzanie strategiczne. Koncepcje metody. Wrocław : Pub. Wydawnictwo Akademii Ekonomicznej we Wrocławiu, 2007. ISBN 978-83-7011-867-9.

LESTYÁNSZKA ŠKU゚RKOVÁ, K. - KUDIČOVÁ, J. 2011. The procesS capability study of pressing process for force closed. In Vedecké práce MtF STU v Bratislave so sídlom v Trnave, vol. 19, 2011, no. 30, pp. 51-57.

PRUSAK, R. - KARDAS, E. - SKUZA, Z. 2012. Analiza strategiczna działalności przedsiębiorstwa przewozowego. In Logistyka, 2012, no. 6, pp. 236-238.

PUSTĚJOVSKÁ, P. - JURSOVÁ, S. - BROŽOVÁ, S. - PIVKO, M. 2012. Injection of brown coal tar in relation to significant parameters of blast furnace. In Materiali in tehnologije, vol. 46, 2012, no. 6, pp. 673-676.

\section{Contact address:}

Manuela Ingaldi, Czestochowa University of Technology, Faculty of Management, Institute of Engineering Production, al. Armii Krajowej 19b, 42-200 Czestochowa, Poland, e-mail: manuela@gazeta.pl 